\title{
Social and Administrative Dimensions of Urban Transformation and Urban Identity: Sample of Yozgat (Turkey) ${ }^{1}$
}

\author{
Seçil Gül MEYDAN YILDIZ*, Hazal Ilgın BAHÇECİ BAŞARMAK**, Emine Saka AKIN*** \\ ABSTRACT
}

The methods and tools, which increase the quality of life, change based on the macro form of the cities and the level of urbanization. As a matter of fact, reasons such as the property system, expropriation practices, lack of resources and lack of urbanization make it technically and financially difficult to re-plan the cities. Urban transformation projects are carried out in order to overcome these difficulties and reorganize the worn out, aging and unhealthy areas of the cities. In this study, the city of Yozgat, which is a medium-sized city model and there is no scientific study on urban transformation applications, was chosen as a sample area. The factors that led to the spread of the concept of urban transformation in Yozgat were explained by using the literature review method, field research, on-site observation, examination and survey methods. At the same time, the causes of urban transformation, its implementation stages and its effects on urban identity were evaluated by using the survey method in legal, administrative dimensions and in line with the participation of citizens. Another aim of this study is to evaluate the compliance of the Old Industrial Zone Area, one of the urban transformation projects in Yozgat, with the national legislation and to examine the relationship between the fragmented urban transformation applications with the urban identity and the whole city.

Keywords: Urban Transformation, Urban Identity, Law No. 6306, Yozgat

JEL Classification: R1

\section{Kentsel Dönüşüm ve Kentsel Kimlik Algısının Sosyal ve Yönetimsel Boyutu: Yozgat Kenti Örneği}

öz

\begin{abstract}
Yaşam kalitesinin artırılmasını sağlayan yöntem ve araçlar kent makroformuna ve kentlileşme düzeyine göre farklılaşmaktadır. Nitekim özel mülkiyet sistemi, kamulaştırma uygulamaları, kaynak yetersizliği ve kentlileşememe gibi nedenler kentlerin yeniden planlanmasını teknik ve maddi açıdan zorlaştırmaktadır. Bu zorlukları aşmak ve kentlerin yıpranan, eskiyen ve sağlıksız gelişen mekân parçalarını yeniden düzenlemek amacıyla kentsel dönüşüm projeleri yapılmaktadır. Bu çalışmada, orta büyüklükteki bir kent modeli olan ve kentsel dönüşüm uygulamalarına yönelik bilimsel bir çalışmanın olmadığı Yozgat kenti örnek alan olarak seçilmiştir. Yozgat kentinde kentsel dönüşüm uygulamalarının yaygınlaşmasına yol açan etmenler, literatür tarama metodu, alan araştırması, yerinde gözlem, inceleme ve anket yöntemleri kullanılarak açıklanmıştır. Aynı zamanda, kentsel dönüşümün nedenleri ve uygulama etapları ile kentsel kimliğe etkileri yasal, yönetsel boyutta ve kenttaş katılımı doğrultusunda anket yöntemi kullanılarak değerlendirilmiştir. Yozgat kentindeki kentsel dönüşüm projelerinden Eski Sanayi Bölgesi'nin ulusal mevzuata uygunluğunun değerlendirilmesi ve parçacıl tasarlanan kentsel dönüşüm uygulamalarının kent kimliğiyle ve kent bütünüyle ilişkisinin irdelenmesi bu çalışmanın bir diğer amacıdır.
\end{abstract}

Anahtar Kelimeler: Kentsel Dönüşüm, Kent Kimliği, 6306 sayılı Kanun, Yozgat

JEL Sinıflandırması: R1

Geliş Tarihi / Received: 17.09.2021 Kabul Tarihi / Accepted: 21.11.2021 Doi: 10.17541/optimum.997034

\footnotetext{
${ }^{1}$ This study is derived from a project named "Effects of Urban Transformation Projects on Socio-spatial Structure: Example of Yozgat" which was supported by the Scientific Research Project Fund of Yozgat Bozok University.

* Doç. Dr., Yozgat Bozok Üniversitesi, Mühendislik-Mimarlık Fakültesi, Şehir ve Bölge Planlama Bölümü, secilmeydan@gmail.com, ORCID:0000-0001-9869-4159

** Doç. Dr., Ankara Hacı Bayram Veli Üniversitesi, İ̈BF, Adalet Yönetimi Bölümü, hazalilgin@gmail.com, ORCID:0000-0003-3967-0960

**** Doç. Dr., Yozgat Bozok Üniversitesi, Mühendislik-Mimarlık Fakültesi, Mimarlık Bölümü, sakin7@ @otmail.com, ORCID:0000-0001-5887-5553
} 


\section{INTRODUCTION}

The city is an evolutionary phenomenon that directs the lifestyle of the society beyond a physical place where vital needs such as shelter, work, rest, entertainment and transportation are met (Keleş, 1998: 125-126). Urban planning is the basic key to a healthy, balanced and orderly development that ensures the establishment of human and social relations within the framework of administrative and legal bases, as well as the perception of environmental conditions, historical and cultural values as a whole (Keleş, 2004: 34-44; Zhou et al., 2021: 4-5). Today, it has become extremely common to rehabilitate and revitalize cities completely or partially in both developed and developing countries (Kropf, 2011: 159). With the urban transformation practices implemented in this framework, it is aimed to improve the quality of life and strengthen the urban economy by improving both economically and physically depressed areas of the cities (Cervelló-Royo et al., 2012: 53).

The first aim of this study is to consider the urban transformation projects in Yozgat, which is a medium-sized city, as a whole with their economic, spatial and socio-cultural dimensions. The second aim of this study is to examine the impact of the widespread implementation of urban transformation projects on the national scale on the macroform of Yozgat and, in this direction, to evaluate the emergence and development of the process depending on the socio-cultural and economic structure of the city, and to make inferences and suggestions for the future projects. The basic assumption of the study is that an urban transformation process that will preserve the urban identity of Yozgat, increase the quality of life and reach contemporary living standards is only possible with the participation and awareness of the citizens. For urban transformation practices compatible with a sustainable land management, the legal, technical and administrative structure of the transformation must be developed with the participation of citizens. The importance and necessity of citizen participation process will be evaluated through the sample area. It is extremely important for the urban transformation projects to be carried out in a healthy way so that the awareness raising activities and trainings of citizens are carried out in cooperation and coordination with the local government units (Keleş and Mengi, 2021: 65).

Policies carried out on the basis of urban transformation in urban space should increase the quality of life and ensure the formation of a healthy, balanced and orderly urban macroform (Kropf, 2011: 158; Naseeb et al., 2021: 78). However, a planning and design process that is detached from the understanding of protecting and keeping the natural and cultural values of the city alive and from holistic sustainable policies can lead to new urban, environmental and vital problems, as well as cause spatial disintegration, social tensions, unfair rents and loss of identity (Capolongo et al., 2019: 10; Trisciuoglio et al., 2021: 3-4). In this process, the coordination of local government units, universities and non-governmental organizations become important. In this study, a survey was conducted to evaluate whether the Old Industrial Zone transformation project in Yozgat center increased the knowledge of the people in urban transformation and distribution of rights, and also to measure their perceptions on urban transformation projects. In this framework, the attractiveness of the appearance that the transformation brings to the city and the contribution of these practices to the preservation and development of the urban identity as well as to a spatial improvement are examined and evaluated.

\section{MATERIALS AND METHODS}

When consider the reasons that reveal the need for urban renewal and urban transformation in Turkey, it is seen that these reasons are closely related to a number of problems caused by the urbanization experience unique to Turkey. Population agglomerations, 
disaster hazards and risks, and the problems caused by the unhealthy urbanization process in Yozgat appear as factors that create the need for urban transformation.

Urban transformation practices are one of the important urban development dynamics of our age, each stage of which should be developed with transparent, accountable and participatory methods by adopting policies to strengthen and revitalize historical accumulation and cultural richness. It is aimed that this study will create a sensitivity in the urban decisions to be taken and the urban policies to be carried out in Yozgat in terms of the method to be followed and the suggestions to be made. In the transformation area of Yozgat, which does not bear any risk due to the ground structure and is subject to the transformation project only due to the insecurity of the building, the poor quality of the urban space and the risk of flooding, the importance of a policy process to ensure that the residents of the project border live in a safer, healthy and balanced environment after the implementation is revealed.

The increase in social awareness and quality of life to be achieved through urban transformation projects will enable the acceptability of new urban transformation areas and the diversification of Yozgat's urban economy, thus enabling a more planned development of the city. In this study, a literature review method was used in the detailed analysis of the spatial and socio-cultural impact of the urban transformation projects implemented and to be implemented in Yozgat, the survey technique with the city residents at the stage of evaluating the participation of the citizens, and in-depth interviews were made with the local administrators and the headmen of the neighborhoods during the examination of the urban transformation process. Totally 1000 participants' results were evaluated in the SPSS program for the analysis of the data obtained by in-depth interview and face-to-face survey technique. While conducting the survey method, which is an important step in the process of accessing scientific data, the staging method was used, starting from public institutions and organizations within the necessary hygiene, distance and mask rules, considering the effects of the pandemic process. Then, on-site observations and field surveys were evaluated by digitizing with mapping and planning methods. The universe of Yozgat city center is considered sufficient to represent the universe with the randomly selected number of participants in accordance with the statistical demographic analyzes on the basis of the neighborhood, and urbanization and urban consciousness evaluations are handled throughout the city center. In this context, the Old Industrial Zone Urban Transformation Project, which is the subject of urban transformation, was evaluated in accordance with the principles of public administration, urbanism and architecture, and a field study was conducted.

Another aim of the urban transformation projects, which aim to get rid of the unplanned construction order, to renew the aging building blocks and to improve the living conditions, is to protect the urban identity. In line with these principles, the conditions of the Old Industrial Zone Urban Transformation Area before and after the transformation were compared and evaluated by both field research and survey method and the awareness of the citizens in the transformation practices was measured.

\subsection{Legal and Administrative Dimensions of Urban Transformation Projects}

The historical development process of urban transformation practices in our country is very new. In addition, Article 56 of the Constitution decrees that "everyone has the right to live in a healthy, balanced and safe environment" and imposes duties on the state in this regard Again, duties regarding urban transformation practices have been assigned to the state with the provision of "ensuring social and economic development, realizing healthy and orderly urbanization" in Article 23 of the Constitution. The fundamental basis of urban transformation practices in our country is the Law No. 6306 on Transformation of Areas Under Disaster Risk. The Law was approved by the Official Gazette dated 31.05.2012 and numbered 28309, and the 
Implementation Regulation prepared for this Law was published in the Official Gazette dated 15.12.2012 and numbered 28498.

Building-based and spatial applications can be made within the Law No. 6306 on Transformation of Areas Under Disaster Risk. In the Implementation Regulation of the Law, the administrative structure that can play a role in the administrative structure is limited to municipalities within the boundaries of municipalities and contiguous areas, special provincial administrations outside these borders, metropolitan municipalities in metropolitan cities, and district municipalities within the boundaries of metropolitan municipalities if authorized by the Ministry of Environment and Urbanization. Institutions that carry out transformation projects in the field of application are the Ministry and the Administration and Housing Development.

The purpose of the law is to determine the procedures and principles for improvement, liquidation and renewal in order to create healthy and safe living environments in accordance with science and art, norms and standards in areas under disaster risk and on lands and lands with risky structures outside these areas.

Within the scope of the law, aimed at making areal applications; the Risky Area, Reserve Structure Area, Application Area definitions are made and how the applications related to these areas will be made is explained. Risky areas are areas that carry the risk of causing loss of life and property due to the ground structure or the construction on it, determined by the Ministry or the Administration by taking the opinion of the Disaster and Emergency Management Presidency and decided by the President upon the proposal of the Ministry.

The risky area is evaluated within the scope of the ground structure and the construction on it. Areas where seismicity, landslides may occur, stream beds, flood zones, areas with the possibility of avalanche or rockfall define the risky areas within the scope of the ground structure. The risky areas within the scope of the construction on it are evaluated as the buildings to be risky due to the fact that most of the buildings are unlicensed and illegally or they have not received engineering services during the project and implementation phase, the transportation network and infrastructure formed as a result of the construction are insufficient, etc. In order for an area to be identified as a risky area, the minimum size of the area should be $15,000 \mathrm{~m}^{2}$. In the applications to be made in Risky Areas, it is essential to agree with the owners first.

\subsubsection{Urban Transformation Implementation Process}

- Municipalities and Special Provincial Administrations should first determine the current situation in their jurisdictions,

- Determining the risky areas due to the ground condition or the construction on it and prioritizing these areas,

- Establishing a holistic transformation strategy by identifying Risky Areas and Reserve Structure Areas,

- In this process, it is necessary to identify the risky structures that require urgent intervention and ensure their demolition, and to ensure the immediate transformation of the identified emergency risk areas (Table 1 and Table 2). 
Table 1: Urban Transformation Implementation Stages

Risky Area Announcement
- Suspension of Business and
Transactions Carried out by
Relevant Administrations in the
Area
- Execution of Current Situation
Analysis and Base Studies
- Determination of Entitlement
- Valuation Activities

\section{Liquidation of Existing} Buildings

- Preparation and Approval of

Parceling Plan

- Construction Process -

Approval of Projects -

Construction Tenders - License

Procedures

- Transfer to Right Holders

Reference: (Created by the Authors).

At the highest level, with plans and projects that emphasize the identity of the area, including special details for the natural, cultural, historical and social characteristics of the area and the sections that are important for users, for the entire planning area and for each implementation phase; identity-image work, building-open space arrangement studies aiming to design the building and its environment with a holistic approach at the medium level, at the lower level; 1/1000 and/or 1/500 scale Urban Design Project is being prepared, which includes the design of spaces between buildings and proposes solutions on issues such as feasibility, livability, sustainability and cost.

After the determination of the right ownership in the project area and the creation of the Valuation Reports, the "Compromise Sharing Model" is created for implementation. Within the framework of Law No. 6306 on Transformation of Areas Under Disaster Risk and Expropriation Law No. 2942; reconciliation is achieved with the citizens who have rights. Article 73 of the Municipal Law No. 5393 gives authority to municipalities on urban transformation. Municipalities can implement urban transformation and development projects in order to create residential areas, industrial areas, commercial areas, technology parks, recreation areas and all kinds of social facilities, to rebuild and restore old parts of the city, to protect the historical and cultural texture of the city or to take measures against earthquake risks in progress by the decision of the city council.

In order for an area to be declared as an urban transformation and development project area, one or more of the above-mentioned issues must occur and this area must be within the boundaries of the municipality or the adjacent area. However, in order for an urban transformation and development project area to be declared and implemented in areas that are owned or used by the public, a decision must be taken by the President, upon the request of the relevant municipality. The Ministry of Environment and Urbanization has been authorized by the President of the Republic to take the decision regarding the urban transformation areas that are publicly owned. Within this context, work and transactions continue in accordance with the "Communique on the Procedures and Principles of Declaring Urban Transformation and Development Areas in Places under Public Ownership or Use", which entered into force after being published in the Official Gazette dated 04.07.2012.

Transformation Projects Special Account Income, Expenditure, Credit and Resource Transfer Regulation determines the fundamentals on the procedures regarding the acquisition, collection and follow-up of the revenues of the special account of transformation projects, the use of the amounts transferred from the budget to this account in the grant or lending programs to be carried out within the scope of the transformation activities, the undertaking, accounting and auditing of all kinds of construction, goods and service procurement, and the operation of the special account. Financial supports provided within the scope of the regulation are 1) 
housing and workplace loan, 2) rental assistance, 3) fix loan, 4) demolition loan, 5) interest support, 6) resource transfer, 7) reinforcement loan.

According to the characteristics of the area in the plans to be made for the application area, it is essential to reduce disaster risks, improve, protect and develop the physical environment, ensure social and economic development, increase energy efficiency and climate sensitivity and quality of life. The purpose of the planning and design studies to be carried out within the scope of the Law No. 6306 is not to increase their current density, not producing land or generating income for the relevant administration. It is to increase the quality of construction and life, and therefore to reduce disaster risks.

According to the Law No. 5366 on the "Renewal, Protection and Use of Worn Historical and Cultural Immovable Assets", the renewal areas are determined by the decision of the absolute majority of the total number of members of the provincial council in special provincial administrations and of the municipal council in municipalities. Decisions taken by the provincial council in special provincial administrations and by the municipal council in municipalities other than metropolitan cities are submitted to the Presidency upon the proposal of the Ministry of Environment and Urbanization. In metropolitan cities, the decisions taken by the district municipal councils are submitted to the Presidency upon the proposal of the Ministry of Environment and Urbanization, upon approval by the metropolitan municipal council.

Municipal Law No. 5393 states that the municipalities can implement urban transformation and development projects in order to create residential areas, industrial areas, commercial areas, technology parks, public service areas, recreation areas and all kinds of social facilities, to rebuild and restore old parts of the city, to protect the historical and cultural texture of the city or to take measures against earthquake risk with the decision of the municipal council of municipalities. Declaring an urban transformation and development project area and making implementation in places owned or used by the public depends on the decision of the Council of Ministers.

Metropolitan municipalities are authorized to declare urban transformation and development project areas within the boundaries of the metropolitan municipality and the adjacent area. District municipalities can implement urban transformation and development projects within their own borders, if approved by the metropolitan municipality council. Except for the education and health areas within the urban transformation and development areas, the public real estates are transferred to the municipalities at the base value. One quarter of the relevant taxes, duties and fees are collected for individual buildings to be demolished and rebuilt in urban transformation and development project areas. The urban transformation area must be located within the boundaries of the municipality or the adjacent area.

The area to be announced as an urban transformation and development project area is the municipal council's sole discretion to decide whether there are areas with or without a building on it, with or without zoning, the determination of the height and density of the building, the size of the area being between minimum 5 and maximum 500 hectares, and it can be done in stages. More than one place related to the project area can be determined as a single transformation area, provided that the total is not less than 5 hectares. The way of agreement is essential in the evacuation, demolition and expropriation of the structures in the urban transformation and development project areas. The lawsuits to be filed by the real estate owners and the municipality within the scope of the urban transformation and development project are first discussed and decided in the courts. 


\subsection{Effect of Urban Transformation Practices on Urban Identity and Social Life}

Urban transformation is a comprehensive and holistic vision and set of actions to ensure the continuous improvement of the economic, physical, social and environmental conditions of an urban area (Roberts, 2000: 123). In this framework, urban transformation practices serve two different basic purposes. The first of these is the integration of settlement areas, which have lost their former social, cultural and economic importance in the historical areas of cities, into urban life. The second one is providing suitable conditions for a legal and healthy life for unqualified and illegal settlements, which were mostly carried out informally in the fringes of cities as a result of unplanned migration.

Urban transformation practices are of vital importance in order to establish a direct relationship between the physical and social elements that arrange the urban space and thus to respond to the need for constant change of many different elements that make up the city (Li et al., 2018: 2). In this respect, urban transformation practices constitute an important part of rational urban policies and urban planning. Since urban transformation covers a very large area, it includes many different areas. These can be listed as rehabilitation of slum areas, improvement of slum areas, transformation of central business areas, transformation for tourism purposes, gentrification, protection and improvement of historical city centers, and urban transformation due to natural disasters (Keleş ve Mengi, 2019: 70). Since Turkey is a country that started its industrialization process late, there was no serious urbanization process until the 1950s, and until this period, there were not many cities that received immigration and urbanized, except for metropolitan cities such as Istanbul and Ankara (Bahçeci and Görmez, 2018: 110). With the 1950s, agricultural mechanization, population growth, the use of radio, the establishment of road networks, and the industrialization experiments carried out by the state in the 1930s triggered migration from rural to urban in Turkey, which started the migration from rural to urban areas. Migration, which was limited and local in the beginning, became massive after the 1950s and caused Turkey to enter into a rapid and unhealthy urbanization process. There are two main reasons for the emergence of this result (Bahçeci and Görmez, 2018: 118).

The first of these is that the housing deficit that emerged during the urbanization process could not be eliminated, and the housing problem of those who came to the city was met with unhealthy buildings called shanty houses, especially in the 70s and 80s, and in the 1980s most of the large-scale cities such as Istanbul, Ankara, Izmir, Adana were covered with slums. The second one is the unplanned growth of cities around the historical city core without any conservation policy. Since changing living conditions, technology, etc. change people's needs and expectations, the functional sustainability of historical buildings that give cities their identity gains importance. Since the sustainability of historical textures and structures in fast and unplanned growing cities in Turkey is not done in a healthy and scientific way, historical structures that cannot meet today's functions have been abandoned and city centers have become areas of collapse (Akın and Özen, 2013: 21-23).

The collapse of the city center caused high-income groups to flee to the periphery of the cities, and there was generally a process of formation of secure housing estates. Although examples and practices of urban transformation in the world date back to ancient times, Turkey only started to meet this subject in the $1980 \mathrm{~s}$, both of these situations necessitated the implementation of urban transformation practices in the central areas of the cities. In mediumsized cities, urban transformation projects gained importance and started to be implemented in the 2000s. The relationship between urban transformation and urban identity stems from the fact that urban development, which is an irresistible process, also affects the transformation and transformation of urban identity. In the most general terms, the identity of the city, which defines the meaning of the relevant place as all the features that distinguish a city from others because it belongs to that city, occurs in a dynamic process and is affected by many developments in the 
historical process. Therefore, urban identity, which can change in the historical process and can be defined in different ways by different people or groups, people's references to the city, unique morphology, unique spatial relations, relations between the city and the user over time and their traces in physical space, rituals, natural and it consists of parameters such as cultural factors and usage habits (Uçar ve Rifaioğlu, 2011: 65). In order for these parameters to be meaningful in terms of urban identity, it is necessary to determine the reference points of the users about the city and to reveal the meanings that they attribute to the urban space. This is difficult because the people and social groups using the urban space have different characteristics from each other and socio-economic conditions create complex relationships. The necessity of discovering and revealing the meanings of the city for the users in the past, as the city contains the collective memory as a historical phenomenon, is an important part of the process of making sense of the urban identity.

The identity of a city is constituted by the whole of the "things" belonging to that city. Just like the city itself, the formation of identity takes place in a dynamic process and is affected by many developments in the historical process. In this context, urban identity; A meaning-laden unity created by the urbanites and their lifestyles, which affect the image of the city, which has its own characteristics with different scales and interpretations in each city, and which is shaped by physical, cultural, socio-economic, historical and formal factors, and which is created by a long process that extends from the past to the future and is constantly developing (Çöl, 1998: 47).

Therefore, in the formation of urban identity, in addition to the natural and artificial environmental characteristics of a city, the socio-cultural characteristics of the society living in that city and the interactions between all these play an important role. The concept of urban identity has become one of the important topics of discussion in the urbanization literature, especially since the second half of the 20th century, as a reflection of the understanding of protection against the standardizing policies of modernity.

The fact that urban development and transformation is an irresistible process makes it inevitable for urban identities to change and transform in this process. In addition, it should not be forgotten that urban spaces are also an important reflection area of social identity. The fact that all kinds of changes in the social structure create changes on the urban spaces directly affect the urban identity in a way that all kinds of changes in the city affect the society and vice versa. In this mutual interaction process, urban policies and planning practices that ignore social, cultural, natural and historical values, as well as the destruction of the existing identities of the cities, as well as the search for a new identity that emerged in the transformation process brought along a uniformization and therefore these may result with an identity crisis. For this reason, it is important for cities which have identity to preserve and maintain historical, cultural, physical and environmental values for healthy and sustainable cities, and to develop and transform these values in line with contemporary living conditions (Kiper, 2006: 34-36).

In today's cities, especially after urban transformation applications and increasing problems are common on this basis. Against this point of view, which destroys the uniqueness of cities by making cities almost identical to each other, the urban transformation implementation process has important steps to be considered, especially during the research phase (Table 2). 
Table 2: Research Phase of Urban Transformation Implementation Process

\begin{tabular}{|c|c|}
\hline Research Type & Content \\
\hline $\begin{array}{l}\text { Administrative } \\
\text { Data }\end{array}$ & $\begin{array}{l}\text { - Applications of Public Institutions and Organizations } \\
\text { - Investment Programs } \\
\text { - } \quad \text { Projects } \\
\text { - } \quad \text { Court Orders etc. }\end{array}$ \\
\hline Historical Research & $\begin{array}{l}\text { - Information, Important Events such as Periodic, Administrative, Sociological, } \\
\text { Economic etc. Determined Chronologically Within the Historical Process } \\
\text { - } \quad \text { Historical Development (Development / Change of Space in Various Periods, } \\
\text { Formation / Development of the City Center / Site Selection) }\end{array}$ \\
\hline $\begin{array}{l}\text { Economic } \\
\text { Structure }\end{array}$ & $\begin{array}{l}\text { - Industrial Development Potential, Industrial Structure Analysis in Labor } \\
\text { Demand with Production Styles and Capacity }\end{array}$ \\
\hline Social Structure & $\begin{array}{l}\text { - } \quad \text { Social Life and Characteristics, Social Development } \\
\text { - } \quad \text { Social Stratification, Migration } \\
\text { - } \quad \text { Orientation/Trend/Demands of Area Users, Thoughts on the Area } \\
\text { - } \quad \text { Intangible Cultural Heritage Elements (tradition, customs, customs, etc.) }\end{array}$ \\
\hline $\begin{array}{l}\text { Research on Past } \\
\text { and Current Plans }\end{array}$ & $\begin{array}{l}\text { - Previously Prepared Development Plans, Regional Plans, Environmental Plans } \\
\text { etc. Analysis of Upper-Level Plans and Development Plans of Different Scope } \\
\text { and Scales and the Effects of Plan Changes } \\
\text { - Investigating Capacity and Implementation Efficiency of Current Plans, Planned } \\
\text { Implementations, Recurring Plan Change Issues, Unplanned Spontaneous or } \\
\text { Irregular Developments and Analysis of Their Effects }\end{array}$ \\
\hline Property Status- & $\begin{array}{l}\text { - Ownership (Treasury, Public, Foundation, Municipality, Private etc., } \\
\text { Shared/Single Owner) }\end{array}$ \\
\hline $\begin{array}{l}\text { Development } \\
\text { Trends }\end{array}$ & $\begin{array}{l}\text { - Cadastral Structure, Parcel Size Analysis } \\
\text { - Land/Building Values and Speculative Trends (Changes in Prices and } \\
\text { Ownership in the Historical Process and Current Situation) and Rent Analysis } \\
\text { - Development Trends Regarding the City and Project Area } \\
\text { - Settlement Demands for Investor Sectors Regarding Land Use } \\
\text { - Investment and Events }\end{array}$ \\
\hline
\end{tabular}

Reference: (Created by the Authors)

These stages reveal that the effects of urban transformation practices on urban identity are more important in terms of historical and social structure. When these steps are carefully examined, we come across basic spatial strategies that are important for the preservation of urban identity. These basic strategies are;

1. Preservation of historical texture,

2. Abandoning the monotonous structuring, which is foreign to the city, instead of the city's unique architecture,

3. And the new development areas not being opened before the settlement areas of the city centers reach a certain fullness (Ministry of Public Works and Settlement, 2009).

Since urban transformation practices, which are the leading intervention tools, used effectively for the purpose of changing or transforming the urban space, include important interventions to the physical and architectural identities of cities, it is essential that these 
practices to be carried out in a rational and planned manner (Hölscher and Frantzeskaki, 2021: $5)$.

The ongoing relationship between social development and urban social life throughout the history of humanity reveals the necessity of ensuring the continuity of the values that make up the urban identity and protecting them. Urban policies that do not focus on the protection of these values will lead to the formation of unqualified urban environments, and the most important result of this situation in terms of urban social life will be an unhealthy transfer of urban culture. One of the main purposes of urban transformation is to increase the quality of urban life through the creation of qualified physical spaces. In order to achieve this, it is necessary to analyze the local values that make up the identity of a city well.

\section{RESULTS}

Yozgat, which has a deep-rooted history dating back to the Chalcolithic Age, is a settlement area established near Ancient King's Road that connects the east and the west. The city, which was a village of about 20 households in the 16th century, was known as Bozok Sanjak in the Ottoman Period. According to the data of the Turkish Statistical Institute in 2021, the city, which is one of the medium-sized urban models, has a linear structure and developed in the form of oil stains with a total population of 90.163 people. Yozgat, which was founded on a valley, became a bazaar in the 1780s with the commercial areas around Çapanoğlu Mosque, which is located in the historical trade center. The first zoning plan of the city, which became a municipality in 1874, was made by İller Bankası in 1948 (Sakin, 2012: 12). When we examine the historical development process of Yozgat's settlement pattern spatially, it is seen that modern urbanization accelerated after the proclamation of the republic. The purple-colored area within the green zone in Figure 1 is the industrial zone established after the proclamation of the republic. This area is among the socio-spatially worn-out regions (Çatalbaş, 2016: 4; Meydan Yıldız ve Bahçeci, 2018: 1180).

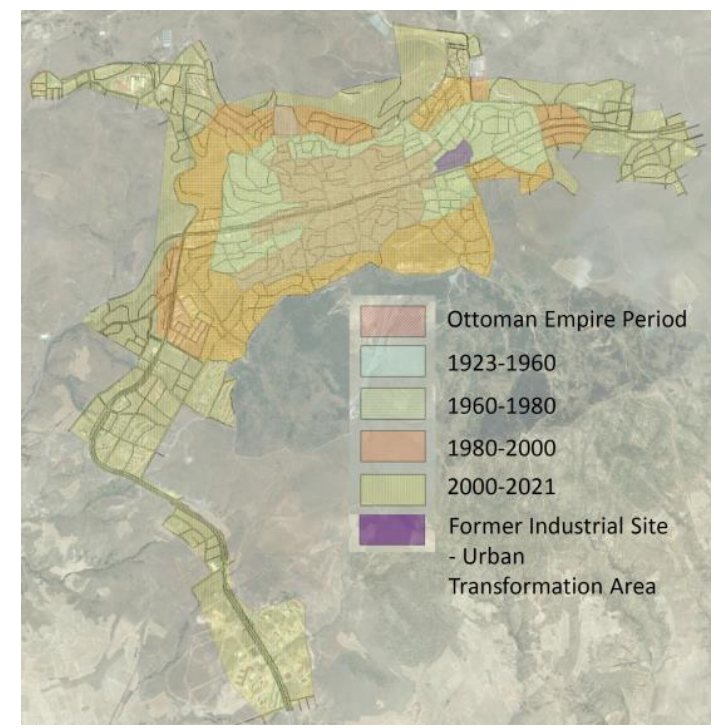

Figure 1: Historical Development of Yozgat

Reference: (Created by the Authors) 
Although there are two water basins in the city, namely Yeşilırmak and Kızılırmak, the northern and eastern regions of the province consist of mountainous areas and large and small streams as landforms. As a result of the inventory information research on flood and flood events carried out by the State Hydraulic Works and Yozgat Provincial Directorate of Disaster and Emergency, it has been determined that flood and overflow events are the first effective type of event among disaster events from past to present in Yozgat. The reason for this is the formation of irregular precipitation regimes caused by the effects of global warming and climate change, as well as the fact that the tops of the streams and streams were closed in the past years, and these regions are confronted as areas where dense populations choose to place, which poses greater problems in terms of urbanization today. When the number of buildings in the city, which consists of 23 neighborhoods, is evaluated according to the construction years, we see that there are 4,500 buildings built before 1990, 3500 built between 2000 and 2010, and 875 buildings built after 2011 (Yozgat Municipality Archive Data, 2021). It has a distorted, irregular city model whose development slows down due to zoning planning and implementation problems, and which develops far from the standards specified in the zoning legislation. The mediumdensity detached, and slum-dominated construction process is shaped by TOKİ projects located in the periphery of the center. Çamlık National Park, the first national park of our country, is the only recreation area of the city and is the most important landscape element that forms the identity of the city (Meydan Y1ldiz, 2019: 302)

The urban transformation area is located in Medrese District, known as the Old Industrial Zone, to the east of the historical trade center. Approximately $60 \%$ of the 56,800 $\mathrm{m}^{2}$ area surrounded by Ankara-Sivas Highway is owned by Yozgat Municipality (Figure 2). Another feature of the area is that since it consists of industrial areas, it causes difficulties in the realization of zoning applications due to its multi-share ownership structure. Therefore, the urban transformation project process started on 27.09.2011 with the cooperation of the Housing Development Administration and Yozgat Municipality, in order to bring the city center from its ruined state to a contemporary, modern and healthy environment, to increase the quality of the urban identity and to ensure the safety of life and property.

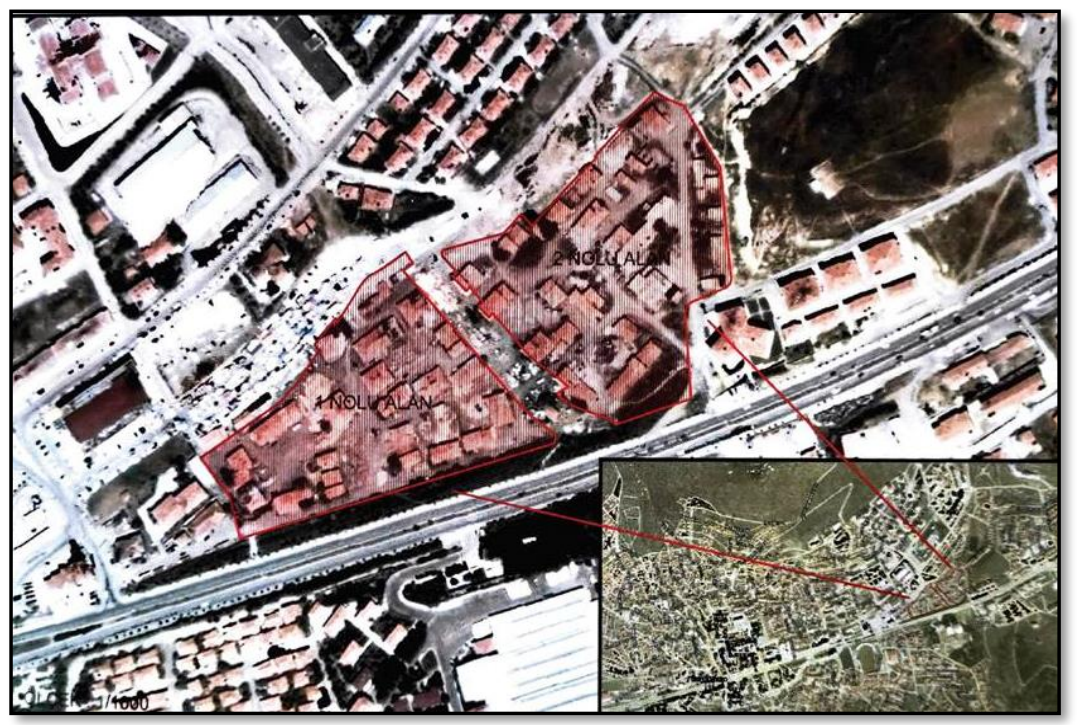

Figure 2: Location of Urban Transformation Zone

Reference: (Created by the Authors) 
In line with the legal basis, according to the Article 73 of the Municipal Law No. 5393, the municipality has declared an urban transformation and development project in order to rebuild and restore the old parts of the city, to protect the historical and cultural texture of the city, and to take measures against the risk of earthquakes and floods. Working areas in the city center, surrounded by commercial uses, pose a threat to quality and security on the one hand, and negatively affect the identity and environmental quality of the city on the other. Yozgat Terminal and Historical Trade Center are located in the west of the area (Figure 3).

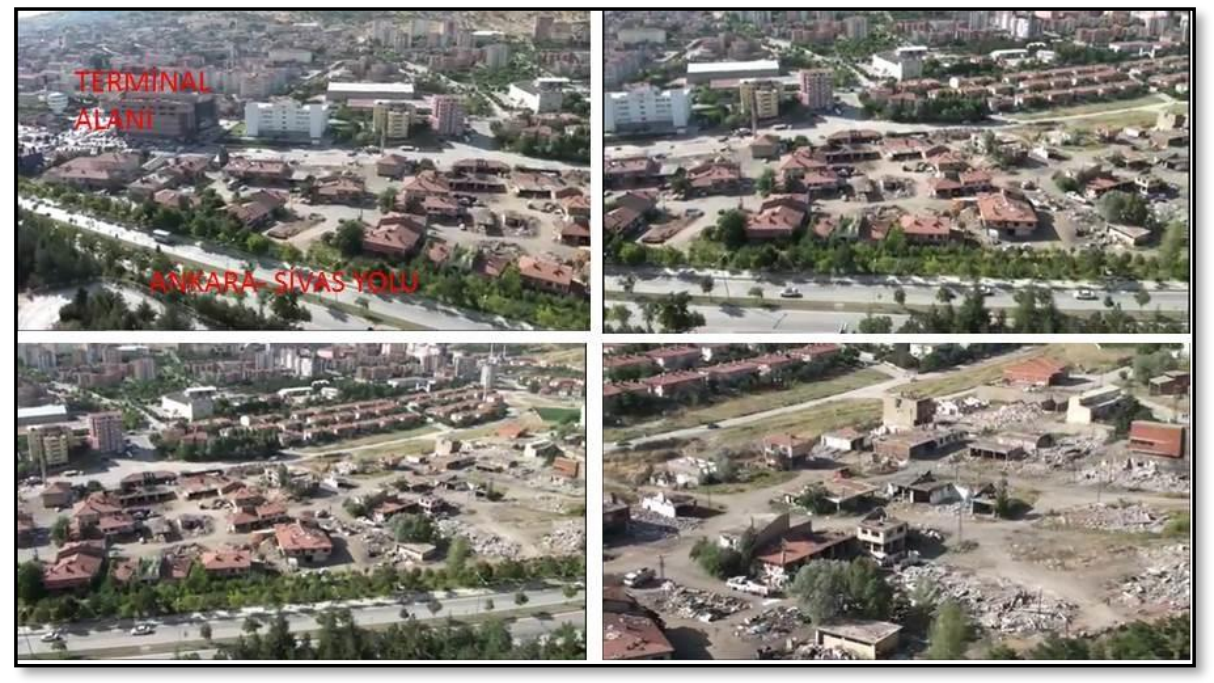

Figure 3: Photos of the Old State of the Urban Transformation Area

Reference: (Yozgat Municipality, 2021).

Considering the current structuring of the region, there have been deteriorations in the social structure and an increase in crime events in the region where the people with low-income groups are concentrated. In order to bring in the economic and social depression region into urban identity, an urban transformation practice, which is one of the methods of intervention in spatial formation, have been applied. In the field, the Valuation Commission Report was prepared on 06.02.2013, and technical examinations were carried out on 22.01.2013 by the Provincial Directorate of Environment and Urbanization. The most important feature of the area is that as a result of the technical examination, it is concluded that it is not a region exposed to disaster. However, it has also been determined that precautions should be taken in the future against the possibilities of floods, flooding, ground liquefaction, etc. The urban transformation stages of the project, which was carried out in cooperation with the Municipality and TOKİ, are as follows. 
Table 3: Urban Transformation Project Stages

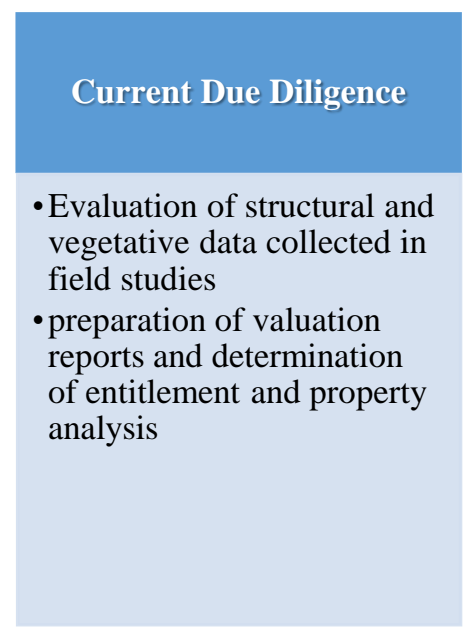

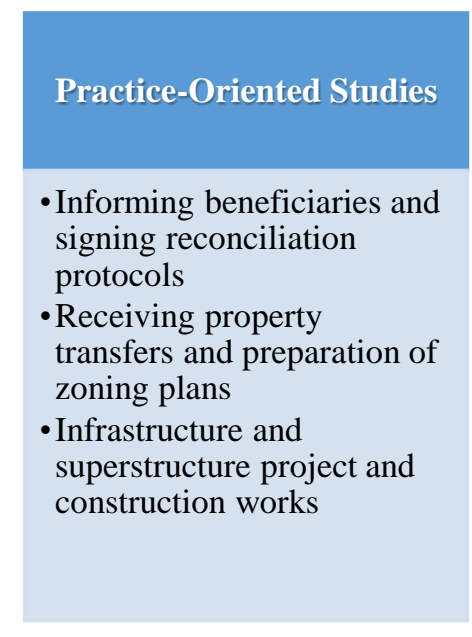

Reference: (Created by the Authors).

Necessary documents were sent to the Real Estate and Expropriation Directorate with the decision of the committee on 13.03.2013, and the urgent expropriation procedures were initiated at an average of $600 \mathrm{TL}$, according to the unit square meter price of the land in 2012. When the stages of the implementation process are examined, it is observed that a research stage listed in Table 4 emerged. The administrative structure of the area, plans and projects were handled and court decisions, property owners and economic structure were discussed in order to avoid property problems. However, it has been determined from the case files and parliamentary decisions that the meetings and informing activities with the property owners during the expropriation process were insufficient, and that the problems arising from the initiation of the reconciliations in the expropriation process without waiting for the realization of all property owners. In conclusion, it is seen that there is a difference between the prices paid in the first month and the current prices paid to the property owners who keep their land in their hands, unconsciously carry out speculative activities. At this stage, the importance of the public's awareness of urban transformation and the fact that local governments act with a transparent and social municipality understanding in the implementation process emerges.

When the details of the project and its effect on the city's face are examined, it can be said that the work that builds a bridge between the center and the periphery was created with design processes that increase density and do not provide spatial continuity. A high-density and fragmented arrangement was preferred instead of the structure shaped by the medium-density and organic development model that forms the urban identity of Yozgat (Figure 4 and Figure 5). 


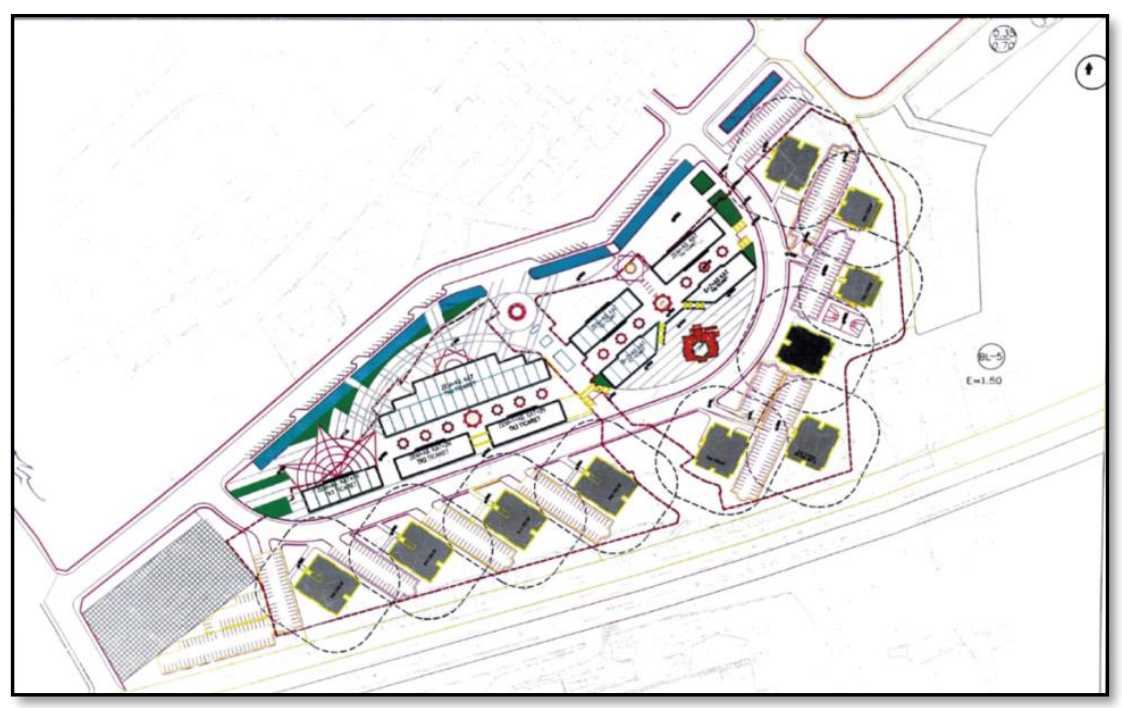

Figure 4: Layout Plan

Reference: (Yozgat Municipality, 2021).
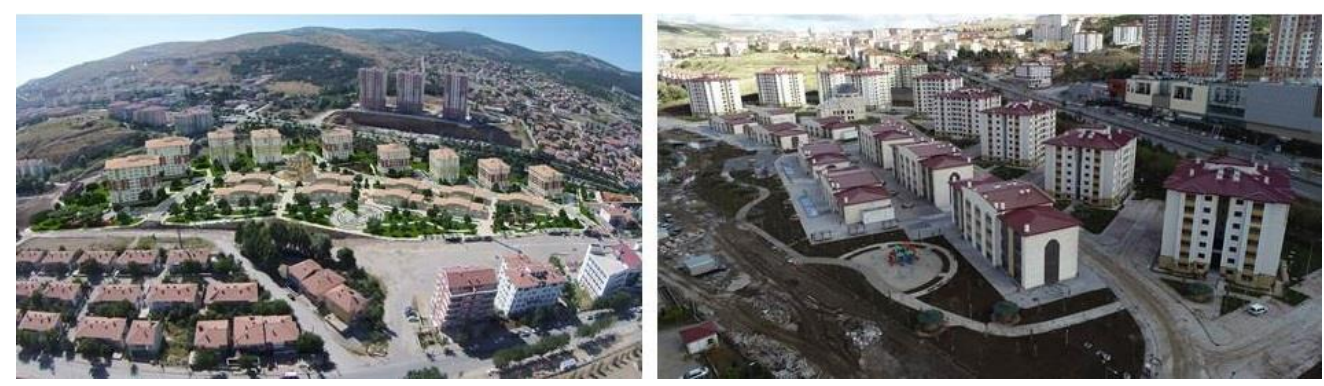

Figure 5: Post-Urban Transformation Photos

Reference: (Yozgat Municipality, 2021).

The survey was conducted to evaluate how the projects that carried out affect the public's awareness of urban transformation and to measure the effect of spatial development, identity gain and visuality that they brought to the city. $75 \%$ of the local people participating in the survey are men and $25 \%$ are women. In the age distribution, $76 \%$ between the ages of $18-45$ and $24 \%$ over the age of 45 . When the educational status of the participants is examined, it is seen that $41 \%$ are high school graduates, $30 \%$ are primary school graduates and $27 \%$ are university graduates. The highest percentage of workers, retired, tradesmen, students, and public servants were included in the sample according to their occupation (Table 4). 
Table 4: General Information of Survey Participants

\begin{tabular}{|c|c|c|c|}
\hline Subject & Options & Answers (Person) & Rate (\%) \\
\hline \multirow{2}{*}{ Gender } & Men & 754 & $75 \%$ \\
\hline & Women & 246 & $25 \%$ \\
\hline \multirow[t]{6}{*}{ Age } & $18-25$ & 323 & $32 \%$ \\
\hline & $26-35$ & 255 & $25 \%$ \\
\hline & $36-45$ & 186 & $19 \%$ \\
\hline & $46-55$ & 153 & $15 \%$ \\
\hline & $56-65$ & 58 & $6 \%$ \\
\hline & Age 65 and over & 25 & $3 \%$ \\
\hline \multirow[t]{4}{*}{ Education Status } & Primary education & 300 & $30 \%$ \\
\hline & High school & 413 & $41 \%$ \\
\hline & University & 273 & $27 \%$ \\
\hline & Illiterate & 14 & $2 \%$ \\
\hline \multirow[t]{12}{*}{ Occupation Field } & Officer & 109 & $11 \%$ \\
\hline & Public worker & 80 & $8 \%$ \\
\hline & Worker in the private sector & 182 & $18 \%$ \\
\hline & Housewife & 62 & $6 \%$ \\
\hline & Artisan & 132 & $13 \%$ \\
\hline & Student & 152 & $15 \%$ \\
\hline & Retired & 126 & $13 \%$ \\
\hline & Businessmen & 14 & $1 \%$ \\
\hline & Self-employment & 80 & $8 \%$ \\
\hline & Farmer & 7 & $1 \%$ \\
\hline & Unemployed & 49 & $5 \%$ \\
\hline & Other & 7 & $1 \%$ \\
\hline
\end{tabular}

Reference: (Created by the Authors)

$54 \%$ of the respondents have been residing in Yozgat since they were born, and the majority of them live in apartments. When the property status is examined, it is seen that home ownership is high. While the rate of those living in buildings aged 31 and over, which can be included in the risky building group, is $37 \%$, housing satisfaction is $66 \%$. It is seen that the people of Yozgat do not prefer the multi-storey site structure and apartment building implemented by TOKI with the urban transformation project, and they mostly want to live in a detached house (52\%). Neighborhood relations and social commitment of being a medium-sized city are supported by the result of being satisfied with the neighborhood at a rate of $71 \%$. The most important problems in the neighborhood are inadequacy of infrastructure (road, water, sewerage) services, insufficient parking, transportation problem, lack of green space, inadequacy of social and cultural activities (Table 5). 
Table 5: Responses of Survey Participants Regarding Housing and Neighborhood

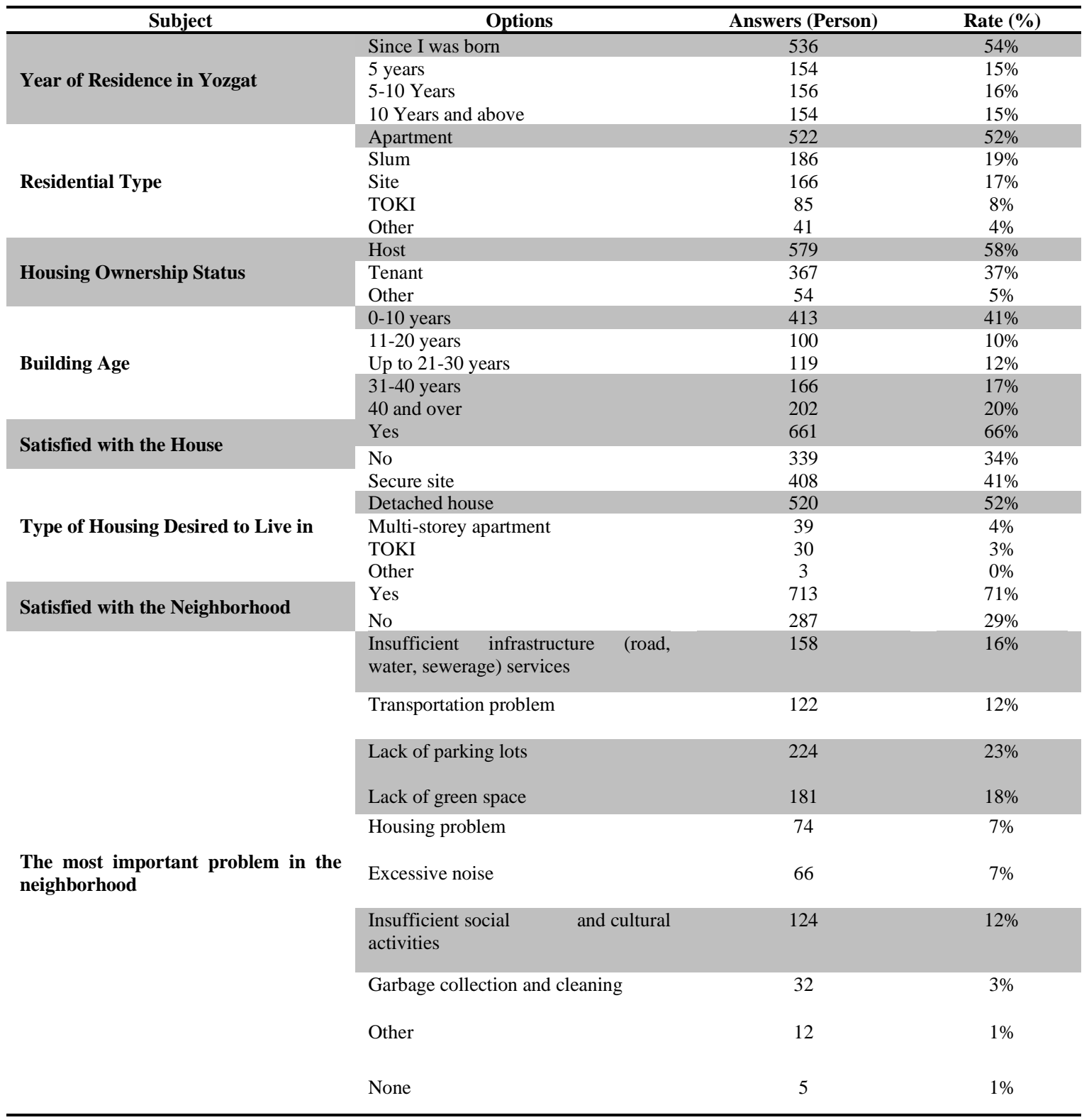

Reference: (Created by the Authors)

$39 \%$ of the respondents define the concept of urban transformation as "destroying old buildings and constructing new ones". When the participants were asked about their opinions on whether the legal regulations in our country about urban transformation were sufficient, $64 \%$ answered "I have no idea". And in response to the question of "Who should be the priority in the urban transformation process?", most of the people (44\%) stated that the opinions of those living in the area and the building are important. On the other hand, it is seen that the interest and desire to participate and take part in the urban transformation process is low (63\%). 95\% of the participants in the research consider urban transformation applications in Yozgat necessary, and 59\% are aware of the urban transformation project in the Old Industrial Zone. The question about the contribution of urban transformation projects to the city was answered by the majority as "the urban view would be better" (38\%) and "quality of life would increase" (33\%). 
According to the crossover result made from the data processed through the SPSS program, $61.6 \%$ of those who answered "yes" to the question "Are you satisfied with the neighborhood you live in?" have also answered "yes" to the question of "Are you aware of the urban transformation project in Yozgat?", and 33.9\% of those who answered "no" said that they were not satisfied with the neighborhood they lived in. In addition, $84.2 \%$ of those who said "I have no idea" about "the adequacy of the legislation for urban transformation", $6 \%$ of those who said "adequate", and $9.8 \%$ of those who said "insufficient" stated that urban transformation is "destroying old buildings and constructing new ones". 64.2\% of those who said "urban transformation is absolutely necessary" in Yozgat said "I am happy to live in Yozgat, but I can leave if I have to", $19.7 \%$ said "Yozgat is a city I will never leave", and 16.1\% said "I will leave Yozgat in the first opportunity" (Table 6).

Table 6: Urban Transformation Awareness of Survey Participants

\begin{tabular}{|c|c|c|c|}
\hline Subject & Options & Answers (Person) & Rate $(\%)$ \\
\hline \multirow{7}{*}{ The meaning of urban transformation } & $\begin{array}{l}\text { Building houses that are sensitive to } \\
\text { natural disasters }\end{array}$ & 124 & $12 \%$ \\
\hline & Regular road and buildings & 152 & $15 \%$ \\
\hline & $\begin{array}{l}\text { Increase in parks, gardens and sports } \\
\text { facilities }\end{array}$ & 80 & $8 \%$ \\
\hline & $\begin{array}{l}\text { Demolition of old buildings and } \\
\text { construction of new buildings }\end{array}$ & 386 & $39 \%$ \\
\hline & Rent & 187 & $19 \%$ \\
\hline & $\begin{array}{l}\text { Increase in the value of property } \\
\text { owners' properties }\end{array}$ & 43 & $4 \%$ \\
\hline & Other & 28 & $3 \%$ \\
\hline \multirow{3}{*}{$\begin{array}{l}\text { Adequacy of legislation on urban } \\
\text { transformation }\end{array}$} & Enough & 122 & $12 \%$ \\
\hline & Not enough & 238 & $24 \%$ \\
\hline & No idea & 640 & $64 \%$ \\
\hline \multirow{7}{*}{$\begin{array}{l}\text { Who should be the priority in the } \\
\text { urban transformation process? }\end{array}$} & Residents of the area-building & 873 & $44 \%$ \\
\hline & Headmen of the neighborhood & 284 & $14 \%$ \\
\hline & Local civil society organizations & 155 & $8 \%$ \\
\hline & Universities & 229 & $11 \%$ \\
\hline & Trade associations & 119 & $6 \%$ \\
\hline & Municipalities & 347 & $17 \%$ \\
\hline & Other & 3 & $0 \%$ \\
\hline \multirow[t]{3}{*}{$\begin{array}{l}\text { Willingness to participate in the } \\
\text { urban transformation process }\end{array}$} & $\begin{array}{l}\text { I would like to participate in the } \\
\text { commissions to be created for a } \\
\text { certain fee. } \\
\text { I volunteer for the working groups to } \\
\text { be formed by the municipality. }\end{array}$ & 130 & $13 \%$ \\
\hline & I don't contribute & 632 & $63 \%$ \\
\hline & Other & 12 & $1 \%$ \\
\hline \multirow{4}{*}{$\begin{array}{l}\text { Opinions on the necessity of urban } \\
\text { transformation in Yozgat }\end{array}$} & Absolutely necessary & 646 & $64 \%$ \\
\hline & Partially necessary & 308 & $31 \%$ \\
\hline & Not required & 28 & $3 \%$ \\
\hline & No idea & 18 & $2 \%$ \\
\hline \multirow{2}{*}{$\begin{array}{l}\text { Awareness of the urban } \\
\text { transformation project in Yozgat }\end{array}$} & Yes & 587 & $59 \%$ \\
\hline & No & 413 & $41 \%$ \\
\hline \multirow{6}{*}{$\begin{array}{l}\text { Contribution of urban transformation } \\
\text { to Yozgat }\end{array}$} & Historical values are preserved & 57 & $6 \%$ \\
\hline & Job opportunities increase & 124 & $13 \%$ \\
\hline & Environmental pollution is reduced & 73 & $7 \%$ \\
\hline & Security increases & 32 & $3 \%$ \\
\hline & Urban view would be better & 382 & $38 \%$ \\
\hline & Quality of life increases & 332 & $33 \%$ \\
\hline
\end{tabular}

Reference: (Created by the Authors) 
$46 \%$ of the respondents described Yozgat as a "boring and monotonous city" and $26 \%$ as a "safe city". According to the people of Yozgat, the three most important urban problems of the city center are respectively as follows: inadequate parking lot, lack of green space and transportation problems and these are followed by "insufficient social and cultural activities" and "insufficient infrastructure (road, water, sewerage) services". According to the participants, the three elements that best symbolize the city of Yozgat are Çapanoğlu Mosque, Çamlık National Park and Clock Tower.The regions most preferred by the participants for shopping and socializing are the historical trade center and its surroundings and Lise Street, which is a part of this region. In this context, it would not be wrong to say that the traditional understanding of trade and street shopping culture continues in Yozgat in accordance with the medium-sized city identity. When the participants were asked about their future plans to live in Yozgat, a large majority of 57\% stated that they were satisfied with living in Yozgat but could leave if they had to (Table 7).

Table 7: Urban Identity Perception

\begin{tabular}{|c|c|c|c|}
\hline Subject & Options & Answers (person) & Rate (\%) \\
\hline \multirow{7}{*}{ Defining Yozgat } & Safe city & 265 & $26 \%$ \\
\hline & Boring-monotonous city & 457 & $46 \%$ \\
\hline & Historical city & 185 & $18 \%$ \\
\hline & Green city & 9 & $1 \%$ \\
\hline & A city of university & 78 & $8 \%$ \\
\hline & Other & 6 & $1 \%$ \\
\hline & $\begin{array}{l}\text { Insufficient infrastructure (road, water, } \\
\text { sewerage) services }\end{array}$ & 390 & $14 \%$ \\
\hline \multirow{8}{*}{$\begin{array}{l}\text { When } 3 \text { are selected among the most } \\
\text { important urban problems of } \\
\text { Yozgat city center }\end{array}$} & Transportation problem & 445 & $16 \%$ \\
\hline & Lack of parking lots & 669 & $23 \%$ \\
\hline & Lack of green space & 583 & $20 \%$ \\
\hline & Health services are inadequate & 121 & $4 \%$ \\
\hline & Cleaning & 54 & $2 \%$ \\
\hline & Excessive noise & 106 & $4 \%$ \\
\hline & Insufficient social and cultural activities & 418 & $15 \%$ \\
\hline & Insufficient education services & 56 & $2 \%$ \\
\hline \multirow{14}{*}{3 items that best symbolize the city } & Other & 7 & $0 \%$ \\
\hline & Capanoglu Mosque & 804 & $27 \%$ \\
\hline & Çamlık National Park & 698 & $23 \%$ \\
\hline & Clock Tower & 674 & $22 \%$ \\
\hline & Desti Kebab & 130 & $4 \%$ \\
\hline & Yimpas & 110 & $4 \%$ \\
\hline & Novada & 59 & $2 \%$ \\
\hline & Lise Street & 241 & $8 \%$ \\
\hline & University & 44 & $2 \%$ \\
\hline & Yozgat High School & 83 & $2 \%$ \\
\hline & Former Military Branch & 20 & $1 \%$ \\
\hline & Çarş1 Bath & 13 & $0 \%$ \\
\hline & Great Cinema & 7 & $0 \%$ \\
\hline & Nohutlu Hill (Sahin Hill) & 117 & $4 \%$ \\
\hline \multirow{6}{*}{$\begin{array}{l}\text { Shopping - socializing regional } \\
\text { preference }\end{array}$} & Bazaar and its surroundings & 407 & $41 \%$ \\
\hline & Lise Street and its surroundings & 292 & $29 \%$ \\
\hline & Yimpas and its surroundings & 102 & $10 \%$ \\
\hline & Novada & 167 & $17 \%$ \\
\hline & Out of city & 27 & $3 \%$ \\
\hline & Other & 5 & $1 \%$ \\
\hline \multirow{3}{*}{ Future plan for living in Yozgat } & Yozgat is a city that I will never leave. & 179 & $18 \%$ \\
\hline & $\begin{array}{l}\text { I am happy to live in Yozgat, but I can } \\
\text { leave if I have to. }\end{array}$ & 571 & $57 \%$ \\
\hline & $\begin{array}{l}\text { I will leave Yozgat in the first } \\
\text { opportunity. }\end{array}$ & 250 & $25 \%$ \\
\hline
\end{tabular}

Reference: (Created by the Authors) 


\section{CONCLUSION}

What makes the city unique when compared to other cities is that it is built on a system of values consisting of different natural features, historical background and cultural accumulation, and only a city with these unique qualities can be described as a city with an identity. Today, the phenomenon of consumption, which has come to the fore with the effect of globalization, has caused significant changes and transformations not only on societies but also on urban spaces. In this process, cities have transformed into a structure that consumes fast, cannot preserve the values they have, and loses their identity over time and, because of the similar structuring trends around the world, it has become uniform and thus different parts of cities in different geographies have gradually become similar to each other. Again, as an important feature of this process, the cities, each of which is tried to be a point of attraction and a center of attraction, have gradually lost their local authenticity and faced the risk of losing their identities while trying to find a place for themselves in the global world. This identity crisis that the cities are in has caused the issue of protection and development of urban culture and urban identity to come to the fore again.

Urban transformation, which is a comprehensive application to improve the economic, physical, social and environmental conditions of a changing urban area, creates many economic, social, cultural and physical effects on the urban space as it involves a physical intervention. Urban transformation practices, which are basically carried out to increase the quality of urban space, should include activities for the protection and development of city-specific values, as well as the creation of a healthy urban structuring with all infrastructure and superstructure equipment. In this context, ensuring the continuity of the culture and historical environment of urban spaces is of great importance in terms of the interaction of urban transformation interventions with urban identity.

In the historical process, urban transformation, which was first used to improve the poor living conditions of the working class after the Industrial Revolution, started to be implemented with the 1950s to clean the poor areas of the cities, and in the 1980s, it was used to generate rent for certain segments with the effect of neoliberal policies and it has become a mechanism that deepens social, class and spatial divisions and creates cities without identity. Although this process takes place all over the world, the experiences of countries differ greatly from each other according to their level of development. In developed countries, this process proceeds through a more participatory, deliberative and transparent planning approach and urban transformation policies sensitive to historical heritage, natural values and human rights are followed. In developing/underdeveloped countries, the course of this process is exactly the opposite and the urban transformation practices, far from participation and transparency, where fait accompli is imposed on the society through political channels, come to the forefront. In this context, the impact of urban transformation practices, which have left their mark on cities in Turkey, especially in the last twenty years, on urban identity constitutes one of the important areas of discussion that does not fall off the agenda.

The first determination to be made when the urban transformation application carried out at Medrese District, known as the Old Industrial Zone of Yozgat, which is a city with an irregular and distorted development course, whose development has been interrupted due to the problems in the development planning and implementation, is evaluated in terms of urban transformation-urban identity interaction, the process is not carried out on the basis of a rational urban planning. The application corresponds to a fragmented arrangement with high density and no spatial continuity, rather than a city with a medium density and organic development model. In addition, the interviews and informative activities with the property owners during the expropriation process are insufficient, and the fact that the project was started without waiting 
for the expropriation process to be realized with all property owners shows that the issue of participation in the process is ignored.

The results of the survey conducted to measure how the project affected the awareness of the people of Yozgat on urban transformation and the identity of the city also confirm these claims. A majority of the people of Yozgat, such as 54\%, stated that they have lived in Yozgat since they were born. About $70 \%$ of them stated that they are satisfied with the residence and neighborhood they live in. Since being a resident in a city for a long time is important for urbanization, this result is positive for urban identity. However, the fact that $63 \%$ of the people do not have an idea about the urban transformation processes and do not want to participate in this process also points to the consequences that may have many negative effects in terms of urban identity. Since urban spaces reflect the identities of the individuals living in the city as well as their own identities, every change that occurs in the city affects the citizens of the city, and every change that occurs in the individuals affects the urban identity. As a result of this interaction, urban identity can preserve or lose its originality. This is the reason why people living in the city should be sensitive to the urban policies carried out in the city they live in and should be willing to participate in the making and implementation processes of these policies. As a matter of fact, the fact that the majority of those who state that they are satisfied with the neighborhood they live in are aware of the urban transformation project carried out in Yozgat, clearly reveals the relationship between the above-mentioned resilience, awareness of being an urbanite, and sensitivity in participating in the decisions taken for the urban living space. At this point, of course, municipalities, which are city administrations, also have important responsibilities. Yozgat urban transformation application example has revealed that the main motivation of the project implementations is independent of the principle that the individuals living in the city can feel themselves belong to that city by establishing a bond with the city as in many other cities of Turkey. City administrations risk the destruction of urban identity in transformation practices in order to create added value in urban space, and they can play an important role in the emergence of cities without identity.

It should not be forgotten that the achievement of urban transformation applications can only be possible in conditions where the urban identity is preserved. As well as having an identity that makes a city different from others and unique, it is also extremely important to implement the necessary regulations and practices for the protection and development of this identity, which shows the importance of the interaction between urban identity and urban transformation. Protection-oriented, integrated and sustainable urban transformation practices are extremely important in order to ensure that the historical and cultural values of the cities are preserved, and their urban identities are transferred to the present day.

\section{Research and Publication Ethics Statement}

This study has been prepared in accordance with the rules of scientific research and publication ethics. This work was supported by the Yozgat Bozok University of Scientific Research Project Fund.

\section{Contribution Rates of Authors}

The contributions of the authors to the article are equal.

\section{Conflicts of Interest}

The authors declare no conflict of interest. 


\section{REFERENCES}

Akin E. S., Özen H. (2013). Reuse problems in historical buildings Tokat Meydan ve Sulu Sokak. Journal of Social Sciences Research, 8 (1), 21-48. [Available online at: https://dergipark.org.tr/tr/pub/gopsbad/issue/48563/616675], Retrieved on 16.06.2021.

Bahceci, H.I., Görmez, K. (2018). Turkey's urban transformation practice, Mengi, Ayşegül and Deniz İşoğlu (Ed.), Urban Politics, Ankara: Palme Yayıncılık.

Capolongo, S., Sdino, L., Dell'Ovo, M., Moioli, R., Della Torre, S. (2019). How to assess urban regeneration proposals by considering conflicting values. Sustainability, 11, 3877. https://doi.org/10.3390/su11143877.

Çatalbaş, F. (2016). Major urbanization problems of Yozgat city center and solution suggestions, Journal of Erciyes University Institute of Science and Technology, 32 (1), 38-47. [Available online at: https://dergipark.org.tr/tr/download/article-file/235966], Retrieved on 1606.2021.

Cervelló-Royo, R., Garrido-Yserte, R., Segura-García del Río, B. (2012). An urban regeneration model in heritage areas in search of sustainable urban development and internal cohesion. J. Cult. Herit. Manag. Sustain. Dev. https://doi.org/10.1080/14649357.2015.1058972.

Constitution of the Republic of Turkey, [Available online at: https://www.mevzuat.gov.tr/MevzuatMetin/1.5.2709.pdf], Retrieved on 16 06.2021.

Desert, S. (1998). The problem of identity in our cities and a method trial to measure the degree of identity of today's cities, Mimar Sinan University Ph.D. Thesis, Istanbul. [Available online at: https://www.researchgate.net/publication/339043281_Kent_Mobilyalarinin_Kentsel_Mekanlarda_Kent_Kimligi_Ile_I liskilendirilmesi_Isparta_Kaymakkapi_Meydani_Ornegi] Retrieved on 16 06.2021.

Expropriation Law No. 2942, [Available online at: https://www.mevzuat.gov.tr/mevzuat?MevzuatNo=2942\&MevzuatTur=1\&MevzuatTertip=5], Retrieved on 16 06.2021 .

Hölscher, K, Frantzeskaki, N. (2021). Perspectives on urban transformation research: transformations in, of, and by cities, Urban Transformations, 3 (2), 2-14. https://doi.org/10.1186/s42854-021-00019-z.

Implementation Regulation of the Law No. 6306, [Available online at: https://www.mevzuat.gov.tr/mevzuat?MevzuatNo=16849\&MevzuatTur=7\&MevzuatTertip=5], Retrieved on 16 06.2021 .

Keleş, R. (1998). Dictionary of urban sciences, Ankara: İmge Kitabevi Yayınları.

Keleş, R. (2004). Urbanization policy, Ankara: İmge Kitabevi Yayınları.

Keles, R., Mengi, A. (2021). City law, Ankara: İmge Kitabevi Yayınları.

Keles, R., Mengi, A. (2019). Zoning law with legal, administrative and political dimensions, Ankara: İmge Kitabevi Yayınları.

Kiper, P. (2006). Preservation of historical-cultural values of cities in the process of globalization; the case of TurkeyBodrum, Istanbul: Social Research Foundation Publications.

Kropf, P. (2011). Urbanism, politics and language: the role of urban morphology. Urban Morphol. 15, 157-161. [Available online at: http://www.urbanform.org/online/pdf2011/201115_155.pdf], Retrieved on 16 06.2021.

Law No. 5366 on the Renewal, Protection and Use of Worn Historical and Cultural Immovable Assets [Available online at: https://www.mevzuat.gov.tr/MevzuatMetin/1.5.5366.pdf], Retrieved on 16 06.2021.

Law No. 6306 on Transformation of Areas Under Disaster Risk, [Available online at: https://www.resmigazete.gov.tr/eskiler/2012/05/20120531-1.htm], Retrieved on 16 06.2021.

Li, X., Wang, M., Liu, X., Chen, Z., Wei, X., Che, W. (2021). MCR-Modified CA-Markov model for the simulation of urban expansion. Sustainability, 10, 3116. https://doi.org/10.3390/su10093116.

Metropolitan Municipality Law No. 5216, [Available online at: https://www.mevzuat.gov.tr/mevzuat?MevzuatNo=5216\&MevzuatTur=1\&MevzuatTertip=5], Retrieved on 16 06.2021 .

Meydan Y1ldiz, S. G. (2019). Women as users of urban squares: investigation of Yozgat city square in the context of design principles and perception of security. 13. International Public Administration Symposium (KAYSEM 13).

Meydan Yıldız, S.G., Bahçeci, H.I. (2018). Evaluation of historical environment in Yozgat city center. III. International Bozok Symposium Regional Development and Socio-Cultural Structure, pp. 1177-1186. 
Ministry of Public Works and Settlement, (2009). Urbanization Council 2009: Urban Transformation, Housing and Land Policies, Ankara, [Available online at: https://webdosya.csb.gov.tr/db/kentges/editordosya/kitap3.pdf], Retrieved on 1606.2021 .

Municipal Law No. 5393, [Available online at: https://www.mevzuat.gov.tr/MevzuatMetin/1.5.5393.pdf (accessed on 16 June 2021).

Naseeb, T.H., Lee, J., Choi, H. (2021). Elevating cultural preservation projects into urban regeneration: A Case Study of Bahrain's Pearling Trail. Sustainability, 13 (12), 6629. https://doi.org/10.3390/su13126629.

Republic of Turkey Ministry of Environment and Urbanization, KENTGES, [Available online at: https://kentges.csb.gov.tr/], Retrieved on 1606.2021 .

Republic of Turkey Ministry of Industry and Technology, Social and Economic Development Ranking of Provinces, [Available online at: http s://www.sanayi.gov.tr/ana Sayfa], Retrieved on 16 06.2021.

Roberts, (2000). The evolution, definition and purpose of urban regeneration urban regeneration handbook. London: SAGE Publications.

Sakin, O. (2012). Bozok Sanjak and Yozgat from history to the present, Istanbul: Eastern Library Publications.

Transformation Projects Special Account Regulation, [Available online at: https://www.resmigazete.gov.tr/eskiler/2017/02/20170225-1.htm], Retrieved on 16 06.2021.

Trisciuoglio, M., Barosio, M., Ricchiardi, A., Tulumen, Z., Crapolicchio, M., Gugliotta, R. (2021). Transitional morphologies and urban forms: production and renewal processes-an agenda. Sustainability, 13, 6233 https://doi.org/10.3390/su13116233.

Turkish Statistical Institute, (2021). Yozgat City Center Address Based Population Registration System, [Available online at: https://www.tuik.gov.tr/], Retrieved on 1606.2021.

Ucar, M., Rifaioğlu, M. (2011). Spatial representation of local identity and its conservation in Québec city. İdealkent, 2 (3), 62-81. [Available online at: https://dergipark.org.tr/tr/pub/idealkent/issue/36633/417050], Retrieved on 16 06.2021 .

Yozgat Municipality, (2021). Archive Data, Yozgat.

Zhou, X., Zhang, X., Dai, Z., Hermaputi, R.L., Hua, C., Li, Y. (2021). Spatial layout and coupling of urban cultural relics: analyzing historical sites and commercial facilities in district III of Shaoxing. Sustainability, 13, 6877. https://doi.org/10.3390/su13126877. 